\title{
Kecerdasan Spiritual dengan Kepuasan Kerja Guru Tahfiz Al-Haramain
}

\author{
Edy Rosw andi, Abdul Sani dan Shanty Komalasari \\ Universitas Islam Negeri (UIN) Antasari Banjarmasin
}

\begin{abstract}
Speaking of teachers, in the present with high urban living needs, if only looking at how the type of work is also at the same time obtaining job satisfaction then most people will choose jobs with more income and leave lower income. Aims to determine the relationship of spiritual intelligence with job satisfaction teacher Tahfiz Al-Haramain Banjarmasin. The hypothesis proposed in this study is that there is a significant positive relationship between spiritual intelligence and job satisfaction. This research is quantitative with purposive sample sampling technique. This research data collection instrument uses a likert scale model and data analysis uses product moment correlation with the help of SPSS. The results of this study indicate that the calculated $r$ value $(0.710)>$ r table (sig $5 \%=0.404$ ) ( $p$ value $<0.05$ ). Then the hypothesis which states that there is a "Relationship between spiritual intelligence and job satisfaction of teachers of Al-Haramain tahfiz Banjarmasin.
\end{abstract}

Keywords: spiritual intelligence; job satisfaction tahfiz Al-Haramain; teacher Banjarmasin

\begin{abstract}
Abstrak
Berbicara mengenai guru pengajar di masa sekarang dengan kebutuhan hidup daerah perkotaan yang tinggi, bukan hanya memandang jenis pekerjaan sekaligus penghasilan dari pekerjaan tersebut, kebanyakan orang memerlukan kepuasan kerja serta akan memilih dengan penghasilan lebih tinggi dan menginggalkan penghasilan yang lebih rendah. Akan tetapi ada banyak faktor yang mempengaruhi seseorang dapat bertahan di pekerjaan mereka, dan pengaruh tersebut berasal dari dalam diri mereka sendiri yang salah satunya adalah berupa kecerdasan spiritual. Maka adanya penelitian ini bertujuan untuk mengetahui hubungan antara kecerdasan spiritual dengan kepuasan kerja pada guru tahfiz Al-Haramain Banjarmasin. Hipotesis yang diajukan dalam penelitian ini adalah terdapat hubungan positif yang signifikan antara kecerdasan spiritual dengan kepuasan kerja. Penelitian ini bersifat kuantitatif dengan teknik pengambilan sampel purposive sampling. Instrument pengumpulan data penelitian ini menggunakan skala model likert dan analisis data menggunakan korelasi product moment dengan bantuan SPSS. Hasil penelitian ini menunjukkan adanya nilai $r$ hitung yang didapat $(0.710)>\mathrm{r}$ tabel $(\mathrm{sig} 5 \%=0.404)(\mathrm{p}$ value $<0.05)$. Artinya pada penelitian ini diperoleh kesimpulan bahwa adanya hubungan positif yang signifikan natara kecerdasan spiritual dengan kepuasan kerja guru tahfiz Al-Haramain Banjarmasin
\end{abstract}

Kata kunci: kecerdasan spiritual; kepuasan kerja; guru tahfiz Al-Haramain Banjarmasin 
Di masa sekarang ini kehidupan manusia jika dilihat melalui segi dalam bertahan hidup, maka yang akan terlihat begitu besarnya keperluan mereka untuk memenuhi segala kebutuhan tersebut melalui pekerjaan. Keadaan dewasa sekarang maka pentingnya suatu pekerjaan yang merupakan keharusan bagi manusia agar terus dapat bertahan hidup, pekerjaan tersebut tentunya halal dan layak untuk seseorang. seseorang tentunya menginginkan pekerjaan yang layak dan sesuai berdasarkan kemampuannya. Dengan adanya itu semua memungkinkan seseorang dapat merasakan adanya kepuasan kerja dalam diri seseorang tersebut. Diketahui bahwasanya manusia selalu menginginkan kepuasan agar kiranya mempermudah dan memperlancar segala urusan terkait dengan pekerjaan tersebut baik bersumber dari pekerjaan yang ditempatinya dan penilaiannya sendiri. Kepuasan kerja menurut Martoyo adalah suatu sarana penting pada manajemen sumber daya manusia dalam sebuah organisasi agar terciptanya kepuasan kerja pada pegawai atau karyawan yang bekerja. (Indri \& Handoyo, 2013).

Terkait dengan kepuasan kerja yang didapat individu ditempat kerja yang sama, maka peneliti disini memiliki alasan untuk mengambil subjek yaitu kepuasan kerja yang ada pada guru tahfiz Al-Qur'an. Disana guru-guru bukan hanya menjadi pengajar bagi anak-anak bahkan orang dewasa juga ikut menjadi murid disana. Murid disana berada mulai dari tingkatan TK, SD, SMP, SMA dan orang dewasa umum yang terlah lulus dari bangku SMA. Kepuasan kerja seseorang tentu kuat kaitannya dengan niat atau motivasi pekerja itu sendiri. Serupa dengan nilai corak budaya kerja guru tahfiz yang memang khasnya nuansa Islami, serta untuk mengetahui dua sisi, sisi pertama yaitu bagaimana cara seorang guru tahfiz merasakan kepuasan kerjadan sisi ke dua ialah cara berpikir mereka untuk memaknai segala sesuatu tersebut yang berkaitan melalui kecerdasan spiritual.

Kecerdasan spiritual dalam Kamus Besar Bahasa Indonesia (KBBI) adalah kecerdasan yang berhubungan dengan hati serta kepedulian bagi sesama manusia, makhluk lain dan alam sekitar merujuk pada keyakinan akan adanya Tuhan Yang Maha Esa (Departemen Pendidikan Nasional, 2013). Kecerdasan spiritual besar kaitannya dan pengaruhnya dengan kepuasan kerja karena bagian dari kepuasan kerja merupakan makna pekerjaan itu sendiri serta motivasi dalam diri, dan motivasi itu juga mempengaruhi dari seberapa besar niat seseorang untuk 
melakukan suatu pekerjaan. Menurut Toto Tasmara kecerdasan spiritual juga merupakan kecerdasan yang terpusat dalam rasa menyayangi dan mencintai yang mendalam kepada Allah SWT dan semua ciptaanNya (Anasrullah, 2015). Kecerdasan spiritual atau ruhaniah ini adalah bentuk kesadaran paling tinggi yang beranjak dari sebuah iman kepada Tuhan. Menurut pendapat Ary Ginanjar Agustian, kecerdasan spiritual adalah kemampuan dalam memberikan makna ibadah kepada berbagai perilaku dan aktivitas, dengan langkah-langkah serta pemikiran yang sifatnya fitrah, menjadikan manusia agar menuju pada fitrahnya yang baik, serta adanya bentuk pikiran yang bertauhid (integralistik) dan juga prinsip niat hidup kepada Allah SWT (Agustian, 2001). Berdasarkan dari latar belakang tersebut maka peneliti ingin mengetahui apakah terdapat hubungan antara kecerdasan spiritual dengan kepuasan kerja pada guru tahfiz Al-Haramain Banjarmasin

\section{Metode}

Metode penelitian yang digunakan dalam penelitian ini adalah penelitian kuantitatif dengan jenis penelitian lapangan atau field research. Seperti yang sudah tertera dari judul, subjek yang digunakan adalah guru tahfiz Al-Haramain Banjarmasin yang berjumlah 66 orang. Teknik yang digunakan untuk memperoleh sampel yaitu dengan metode purposive sampling, yang dilakukan melalui pengambilan subjek yang bukan berdasar atas strata ataupun random, melainkan didasari dengan tujuan yang ditentukan (Sugiyono, 2010). Yang artinya memiliki beberapa pilihan tertentu agar berhasil mendapatkan sampelnya. Sampel tersebut memiliki total jumlah 30 subjek serta terbagi menjadi 4 kategori dan setiap kategori terdapat 6 orang dari subjek yaitu guru yang mengajar tahfiz 6 orang, sugro 6 orang, tahsin 6 orang dan pra tahsin 6 orang.

Pengumpulan data dalam penelitian ini menggunakan 2 jenis skala, yaitu skala kecerdasan spiritual dan skala kepuasan kerja. Skala kecerdasan spiritual dalam penelitian ini disusun berdasarkan aspek dari teori Danah Zohar dan Ian Marshal yaitu kemampuan bersikap fleksibel, memiliki tingkat kesadaran diri yang baik, kemampuan menghadapi dan melampaui rasa sakit, mempunyai visi dan misi hidup, tidak melakukan kerugian yang tidak perlu, berpikir holistic, kcenderungan mencari jawaban dan mandiri (Marchelle, rr). Dan skala 
kepuasan kerja berdasarkan pada aspek dari teori Horald E.Burt yaitu aspek psikologis, fisik, social dan finansial. Selain itu pada penelitian ini juga menggunakan dokumentasi, wawancara dan observasi sebagai data pendukung (McGraw-Hill, 2010).

Analisis data dalam penelitian ini menggunakan analisis statistik. Statistik diperoleh melalui tahapan mulai dari mengumpulkan atau mencari data, penyusunan data, menyajikan dan menganalisa serta penyelidikan yang berupa penyajian angka-angka. Adanya alasan lain dari statistik yang merupakan dasar sifatnya objektif dan bersifat universal yang itu artinya statistik mampu berbeda pada setiap bidang ilmu penelitian untuk diterapkan. Adapun suatu teknik atau cara yang digunakan untuk melakukan penghujian hipotesis adalah dengan teknik analisis statistik dari korelasi yang bernama Carl Pearson (salah satu teknik uji statistik yang ada dalam aplikasi SPSS)

\section{H a s i 1}

\section{Uji Asumsi}

Hasil uji normalitas pada variabel kecerdasan spiritual dan kepuasan kerja menunjukkan nilai signifikansi one sample Kolmogorov sebesar $(0,886>0,005)$. Hal ini menunjukkan bahwa kecerdasan spiritual dan kepuasan kerja memiliki daya yang berdistribusi normal. Hasil uji linearitas untuk variabel kecerdasan spiritual terhadap kepuasan kerja menunjukkan nilai signifikan $(0,379>0,05)$. Hal ini menunjukkan bahwa variabel bebas kecerdasan spiritual dan kepuasan kerja penyebaran titik-titik yang berdasarkan nilai dari variabel-variabel penelitian menunjukkan sebuah hubungan linear antara variabel-variabel tersebut.

\section{Uji Hipotesis}

Hasil analisis untuk uji hipotetsis melalui teknik correlation product moment dari Carl Pearson diperoleh hasil signifikan 0,000 $<0,05$ artinya terdapat hubungan positif yang signifikan antara kecerdasan spiritual dengan kepuasan kerja guru tahfiz Al-Haramain Banjarmasin. Berikut tabel dibawah ini agar lebih jelasnya untuk melihat nilai koelasi atau hubungan dari dua variabel. 


\section{Tabel 1}

Correlasion Product

\begin{tabular}{ccccc}
\hline Model & $\mathrm{R}$ & R Square & Adjusted R Square & Std. Error of the estimate \\
\hline 1 & $.705^{\mathrm{a}}$ &, 497 &, 497 & 6,9817 \\
\hline
\end{tabular}

Pada tabel 1 diatas diketahui bahwa nilai koefisien determinan ( $\mathrm{R}$ square) sebesar 0,497 pengaruh variabel bebas (kecerdasan spiritual) terhadap variabel terikat (kepuasan kerja) ialah 49,7\%, sedangkan nilai $\mathrm{R}$ diperoleh 0,05 artinya ada hubungan positif yang signifikan antara kecerdasan spiritual terhadap kepuasan kerja guru tahfiz Al-Haramain Banjarmasin.

Penelitian ini juga membuat suatu kategorisasi untuk setiap variabel, tujuannya agar menempatkan individu atau subjek penelitian ke dalam kelompok-kelompok yang posisi berjenjang menurut suatu kontinum berdasarkan atribut yang diukur. Berikut dibawah ini tabel yang memaparkan tentang kecerdasan spiritual terhadap kepuasan kerja guru tahfiz AlHaramain Banjarmasin

\section{Tabel 2}

Tingkat Kecerdasan Spiritual

\begin{tabular}{ccc}
\hline Norma & Frekuensi & Persentase \\
\hline Tinggi & 7 & $23,7 \%$ \\
Sedang & 18 & $60 \%$ \\
Rendah & 5 & $16,7 \%$ \\
\hline
\end{tabular}

Berdasarkan tabel 2 diatas diketahui bahwa tingkat kecerdasan spiritual guru Tahfiz AlHaramain Banjarmasin dengan kategori tinggi sebesar 23,7\% (7 orang), sedang 60\% (18 orang) dan rendah 16,7\% (5 orang).

Tabel 3

Tingkat Kepuasan Kerja

\begin{tabular}{ccc}
\hline Norma & Frekuensi & Persentase \\
\hline Tinggi & 5 & $16,7 \%$ \\
Sedang & 21 & $70 \%$
\end{tabular}


Rendah

$13,3 \%$

Berdasarkan tabel 3 diatas diketahui bahwa tingkat kepuasan kerja guru Tahfiz AlHaramain Banjarmasin dengan kategori tinggi sebesar 16,7\% (5 orang), sedang 70\% (21 orang) dan rendah $13,3 \%$ (4 orang).

\section{Pembahasan}

Bekerja sebagai guru tahfiz di tahfiz Al-Haramain atau seorang pengajar yang berbasis agama dan memberikan pelajaran kitab suci Al-Qur'an, serta tanggung jawab besar tentulah memerlukan tenaga dan kesabaran lebih yang harus dimiliki. Ditambah lagi daerah perkotaan yang kebutuhan materialnya saat ini sangat memaksakan seseorang bekerja dengan penghasilan yang sesuai agar dapat menjadi memenuhi kebutuhan seharinya. Di Banjarmasin, khususnya Rumah Tahfiz Al-Haramain, guru-guru bukan hanya menjadi pengajar bagi anakanak bahkan orang yang dewasa juga ikut menjadi murid disana, murid disana berada pada berbagai tingkatan sekolah mulai dari TK, SD, SMP, SMA dan orang dewasa umum yang sudah lulus dari bangku SMA. Menyadari tentang begitu pentingnya untuk memperhatikan guruguru, bukan hanya guru umum saja tetapi guru yang berkaitan dengan agama yaitu seperti salah satunya guru-guru tahfiz agar mendukung lagi kepuasan kerja bagi seorang guru tahfiz dalam hal bekerja mereka yaitu agar mengajarnya dan semakin memperkenalkan ke masyarakat bahwa di daerah perkotaan yang kebutuhan hidupnya lebih banyak. Bahkan dengan menjadi guru tahfiz itu semua belum dapat terpenuhi, karena mayoritas masyarakat perkotaan lebih tahu bahwa untuk dapat memenuhi kebutuhan hidup didaerah perkotaan ialah menjadi PNS, pegawai kantor dan lain sebagainya.

Menurut Robbins, kepuasan kerja adalah sikap umum seseorang dalam menanggapi suatu pekerjaan yang ia rasakan saat itu, perbedaan pada banyaknya yang terjadi dalam pekerjaan dengan penghasilan yang seharusnya seseorang itu peroleh (Marchelle, 2013). Munculnya kepuasan kerja didalam diri seseorang ialah pada setiap kebutuhan yang telah terpenuhi dan terkait pada apapun yang menyangkut pada apa yang disukai atau tidak disukai seseorang tersebut, serta sikap yang umum yang terdapat dari para karyawan atas hasil yang mereka peroleh dari pekerjaan mereka. 
McGraw-Hill (2010) Kepuasan kerja juga mengacu pada sikap umum karyawan terhadap pekerjaan itu sendiri yang dipengaruhi kondisi pekerjaan, gajih yang setimpal dengan pengorbanan, sifat karyawan terhadap perusahaan lalu atasan serta pekerjaan itu sendiri, kesehatan dan umur karyawan.

Menurut pendapat Horald E.Burt adanya faktor-faktor yang dapat menimbulkan kepuasan kerja seperti layaknya hubungan antar karyawan, pimpinan, kondisi fisik, situasi kerja, pengaruh rekan kerja, jenis kelamin, umur, sikap terhadap pekerjaan serta faktor lainnya yaitu pendidikan dan hiburan (McGraw-Hill, 2010).

Ary Ginanjar Agustin (2001) kecerdasan spiritual adalah kemampuan dalam memberikan makna ibadah kepada berbagai perilaku dan aktivitas, dengan langkah-langkah serta sifat berpikir mengembalikan semua kepada sang pencipta, menuju manusia yang seutuhnya (hanif) dan juga berpikir dengan pola ketauhidan (integralistik) yang artinya menyerahkan segala sesuatunya hanya kepada Allah SWT.

Menurut KH. Toto Tasmara bahwa kecerdasan ruhaniah atau kecerdasan spiritual merupakan kecerdasan yang berpusatkan pada rasa cinta yang mendalam kepada Allah SWT dan seluruh ciptaanNya. Kecerdasan spiritual merupakan sifat dari kesadaran paling atas yang dimulai pada keimanan seseorang dengan Allah SWT (Anasrullah, 2015). Kemudian Hidayati (2013) dalam penelitiannya menyebutkan bahwa kecerdasan emosional tidak berpengaruh signifikan terhadap kepuasan kerja dan kinerja, sedangkan kecerdasan spiritual lah yang memiliki pengaruh signifikan terhadap kepuasan kerja dan kinerja.

\section{Kesimpulan}

Dari hasil analisis data dan pembahasan diatas mengenai hubungan kecerdasan spiritual dengan kepuasan kerja guru tahfiz Al-Haramain Banjarmasin, maka diperoleh kesimpulan bahwa adanya hubungan positif yang signifikan antara kecerdasan spiritual dengan kepuasan kerja karena diperoleh angka sebesar 70,5\%

Selanjutnya pada hasil data kecerdasan spiritual. Diperoleh hasil nilai perhitungan SPSS for windows versi 21.0 nilai dari mean pada angket kecerdasan spiritual adalah 104,26 dan 
standar deviasi 10,24, kemudian dari hasil tersebut diperoleh kategori kecerdasan spiritual tinggi $23,7 \%$ (7 orang), standar deviasi sedang 60\% (18 orang) dan standar deviasi rendah 16,7\% (5 orang). Dengan melihat hasil data yang diperoleh peneliti tersebut, kecerdasan spiritual guru tahfiz Al-Haramain berada pada tingkat dominan kategori sedang.

Pada hasil data berikutnya tentang tingkat kepuasan kerja, melalui hasil dari perhitungan dengan SPSS for windows versi 21.0 nilai dari mean pada angket kepuasan kerja adalah 138,26 dan standar deviasi adalah 9,6. Lalu pada hasil itu diperoleh kategori kepuasan kerja dengan tingkat tinggi sebesar 70\% (21 orang), sedang sebesar 16,7\% (5 orang) dan rendah sebesar 13,3\% (4 orang). Dengan melihat hasil data tersebut tingkat kepuasan kerja guru tahfiz Al-Haramain lebih dominan berada pada kategori sedang.

Kesimpulan terakhir terkait dengan hubungan tentu saja juga akan ada pengaruh, berdasarkan hasil data yang telah di uji maka adanya pengaruh kecerdasan spiritual terhadap kepuasan kerja yaitu sebesar $49,7 \%$ yang berada pada kategori sedang.

Saran

Berdasarkan paparan hasil dari penelitian diatas, terdapat beberapa saran yang nantinya bisa saja dijadikan masukan sebagai pelengkap pada penelitian selanjutnya. Serta juga sebagai bahan masukan untuk seluruh guru tahfiz Al-Haramain ataupun guru lainnya bahwa dengan meningkatkan kecerdasan spiritual maka kepuasan kerja juga akan ikut meningkat.

Kecerdasan spiritual tidak lepas kaitannya dengan kecerdasan emosional dan kecerdasan intelektual, oleh karenanya dengan tiga kecerdasan tersebut diharapkan peneliti selanjutnya dapat mengembangkannya sehingga wawasan keilmuan psikologi khususnya psikologi Islam menjadi semakin bertambah.

Kedepannya buku-buku tentang kecerdasan spiritual, kecerdasan emosional dan kecerdasan intelektual. Serta buku tentang kepuasan kerja diperbanyak lagi agar terkhusus bagi masyarakat Fakultas Ushuluddin dan Humaniora dapat mempelajari secara lebih serta dapat mengamalkan bagaimana caranya agar memperoleh kepuasan kerja yang maksimal, serta mendorong kualitas mahasiswa dan dosen yang lebih baik berdasatkan adanya dorongan dari kepuasan kerja tersebut. 


\section{Referensi}

Agustian, A.G. (2001). Rahasia Sukses Menggunakan Kecerdasan Emosi dan Spiritual ESQ: Emotional Spiritual Quotient Berdasarkan 6 Rukun Iman dan 5 Rukun Islam. Jakarta: Arga Widya Persada

Indri, H.H. dan Handoyo, S. (2013) Hubungan Kepuasan Kerja Dengan Motivasi Kerja Pada Karyawan Bank BTPN Madiun, 2(2), 101

Marchelle, S.V. (2013) Pengaruh Kepuasan Kerja dan Loyalitas Kerja Terhadap Organizational Citizenship Behavior Pada Karyawan PT Surya Timur Sakti Jatim. Jurnal Program Managemen Bisnis Universitas Kristen Petra, 1(1), 1-2

Sugiyono. (2010) Metode Penelitian Pendidikan (Pendekatan Kuantitatif, Kualitatf dan R\&D) Alfabeta

Anasrulloh, Muhammad. (2015). Pengaruh Kecerdasan Spiritual Terhadap Kinerja Guru dan Motivasi Kerja Sebagai Variabel Intervening di MTs Darul Hikmah Tulungagung. Jurnal Inspirasi STKIP PGRI, 1(11).12-16

Departemen Pendidikan Nasional. (2013) Kamus Besar Bahasa Indonesia. PT. Gramedia Pustaka Utama

McGraw-Hill. (2010). Supervision: Key Link To Productivity Americas: New York. 72

Hidayati, N.I., Setiawan. M \& Solimun. (2013). Kecerdasan Emosional dan Kecerdasan Spiritual Pengaruhnya terhadap Kepuasan Kerja dan Kinerja Karyawan Studi di Lembaga Penjaminan Mutu Pendidikan(LPMP) Nusa Tenggara Barat. Jurnal Aplikasi Managemen. 11(4). 636-637

Salani, M (2015). Kepuasan Kerja Pada Karyawan Bagian Produksi PT Dystar Colours Indonesia. Jurnal Skripsi Universitas Gunadarma. 5

\begin{tabular}{|l|l|l|l|l|}
\hline Submit & Review & Revisi & Diterima & Publis \\
\hline $23-07-2020$ & - & - & $30-03-2021$ & $22-04-2021$ \\
\hline
\end{tabular}

Edy Rosw andi, Abdul Sani dan Shanty Komalasari

Program Studi Psikologi Islam

Fakultas Ushuluddin dan Humaniora

Universitas Islam Negeri (UIN) Antasari Banjarmasin

Email : edytooffice@gmail.com 